\title{
Determinants of success of donation-based crowdfunding through digital platforms: The influence of offiline factors
}

\author{
Noelia Salido-Andrés, Marta Rey-García, Luis Ignacio \\ Alvarez-González and Rodolfo Vázquez-Casielles
}

ABSTRACT: The purpose of this research consist of exploring the extent to which factors traditionally explaining the success of offline fundraising campaigns for social causes may also influence the success of donationbased crowdfunding (DCF) campaigns promoted by social economy organizations (SEO) through digital platforms. Firstly, factors determining the success of offline fundraising campaigns for social causes are identified from previous literature. Secondly, a set of hypotheses linking these determinants to DCF campaigns is proposed. Thirdly, their explanatory capacity is measured through quantitative analysis based on a database of 360 campaigns fostered by small, medium and large-size organizations via Microdonaciones, a donation-based crowdfunding digital platform, for the period between 2012 and 2017. Logistic regression analysis is used to test the hypotheses proposed. Results confirm the high explanatory capacity of determinants related to the geographical scope of the campaign, the volume of potential beneficiaries involved -in these two cases in unexpected ways-, and the information provided by the promoting organizations. However, factors related to the timing of the campaigns do not influence their success. This research suggests that not only the funding channels and tools but also the nature of the fundraising campaigns themselves have been digitally transformed. Implications of this research may assist SEO in establishing effective relationships with new digital donors in order to achieve sustainable growth.

KEYWORDS: Donation-based crowdfunding; social causes; digital platforms; fundraising campaigns; sustainable social economy organizations.

ECONLIT DESCRIPTORS: L31, 033, O35, M14, D91.

How to cite this article: SALIDO-ANDRÉS, N., REY-GARCÍA, M., ÁLVAREZ-GONZÁLEZ, L.I. \& VÁZQUEZ-

CASIELLES, R. (2019): "Determinants of success of donation-based crowdfunding through digital platforms:

The influence of offline factors", CIRIEC-España, Revista de Economía Pública, Social y Cooperativa, 95, 119141, DOI: 10.7203/CIRIEC-E.95.13001.

Correspondence: Noelia Salido-Andres, Dr. / School of Economics and Business, University of A Coruña; Marta Rey-Garcia, Dr. / School of Economics and Business, University of A Coruña; Luis Ignacio Alvarez-Gonzalez, Dr. / School of Economics and Business, University of Oviedo, and Rodolfo Vazquez-Casielles, Dr. / School of Economics and Business, University of Oviedo, 33006 Oviedo, Spain.

Correspondence: noelia.sandres@udc.es. 


\section{Determinantes del éxito del crowdfunding solidario a través de plataformas digitales: La influencia de los factores fuera de línea}

\section{Objetivo}

En el actual contexto de revolución digital, la promoción de campañas de crowdfunding (CF) basadas en donación - también denominado CF solidario - a través de plataformas digitales está aumentando entre las organizaciones de economía social (empresas sociales, organizaciones híbridas, y entidades no lucrativas (ENLs)) en pro de un crecimiento sostenible. En un escenario igualmente caracterizado por un acceso reducido a las tradicionales fuentes de financiación fruto de las recientes tensiones económicas, esta herramienta en línea complementa, e incluso sustituye, el empleo de las tradicionales campañas de captación de fondos fuera de línea para causas sociales. Sin embargo, y a pesar de la creciente importancia del CF solidario para avanzar con éxito causas sociales, promover valores prosociales, y ayudar a las organizaciones promotoras a ser financieramente sostenibles, la literatura específica emergente todavía es escasa. De un lado, las campañas de CF basadas en préstamo han venido captando la mayor parte de la atención de la literatura sobre CF. De otro, los todavía escasos estudios disponibles sobre las particularidades del CF de tipo solidario se centran más en los efectos que esta herramienta de financiación tiene sobre los donantes individuales que sobre sus efectos en las organizaciones promotoras.

Esta investigación tiene como objetivo final comprender las implicaciones del CF solidario para la economía social y sus organizaciones, de cara a encontrarse en disposición de optimizar las oportunidades derivadas de la presente revolución digital. Para ello, las organizaciones promotoras necesitarán identificar qué factores están determinando el éxito de sus campañas de CF solidario para causas sociales: ¿las reglas de la recaudación de fondos tradicional, fuera de línea, aplican también en la nueva era digital? En este contexto, el principal objetivo de esta investigación es explorar hasta qué punto los factores que explican el éxito de las campañas de recaudación de fondos para causas sociales fuera de línea pueden también explicar el éxito de las campañas de CF solidario promovidas a través de plataformas digitales.

\section{Diseño / Metodología / Aproximación}

Empleando la campaña como unidad de análisis, centramos el foco sobre aquellos determinantes previamente identificados por la literatura sobre el éxito de las campañas de recaudación de fondos fuera de línea, específicamente en relación al alcance geográfico de las causas sociales, el 


\section{DETERMINANTS OF SUCCESS OF DONATION-BASED CROWDFUNDING THROUGH DIGITAL PLATFORMS: THE INFLUENCE OF OFFLINE FACTORS}

volumen de potenciales beneficiarios que se espera asistir, el momento de realización de las campañas, y el comportamiento de las organizaciones promotoras.

El foco de esta investigación se centra en una plataforma de CF solidario externa, especializada, nacional y todo o nada denominada Microdonaciones. Lanzada por la Fundación Hazloposible en 2012, Microdonaciones ha promovido la donación de pequeñas cantidades de dinero a campañas benéficas impulsadas principalmente por ENLs españolas, principalmente fundaciones y asociaciones.

La selección de Microdonaciones como plataforma de crowdfunding solidario para causas benéficas respondió principalmente a los siguientes criterios. En primer lugar, a su relevante papel de intermediación y asesoramiento para con las entidades promotoras, más allá de la centralización de las transacciones monetarias resultantes. Un segundo criterio estuvo relacionado con el hecho de que la selección de campañas benéficas finalmente alojadas en la plataforma estuviese estandarizada por la misma desde el inicio, lo que favoreció la estimación del efecto de los factores hipotéticos sobre el éxito de las campañas. Y por último, un tercer criterio respondió a la posibilidad de analizar los efectos de una plataforma de crowdfunding solidario a lo largo de todo su ciclo de vida, ya que Microdonaciones cesó su actividad como plataforma durante el primer trimestre de 2017, exactamente cinco años después de su lanzamiento en la misma altura del año 2012.

Para poder testar las hipótesis que se formulan, se han recogido datos sobre variables independientes y dependiente - éxito de las campañas de CF solidario - de la página web oficial de Microdonaciones. Se ha construido una base de datos almacenando un total de 360 campañas exitosas y no exitosas promovidas desde el 19 de marzo de 2012, cuando se inició la primera campaña benéfica alojada, hasta el 22 de marzo de 2017, cuando terminó la última campaña. Durante este período de cinco años, las campañas atrajeron más de 9.300 donaciones en línea a través de la plataforma, lo que resultó en 262 campañas benéficas exitosas, el $73 \%$ de las promovidas.

La potencial influencia que los determinantes del éxito de las campañas fuera de línea podrían tener en la probabilidad de alcanzar el objetivo monetario solicitado en las campañas de CF solidario se mide mediante la aplicación de técnicas cuantitativas (i.e. regresiones logísticas) a través del empleo del programa estadístico STATA.

\section{Resultados / Limitaciones a la investigación / Implicaciones}

Los resultados muestran que en el ámbito de las campañas de CF solidario promovidas a través de plataformas digitales, las causas domésticas tienden a ser menos exitosas, mientras que aquellas con un número limitado de potenciales beneficiarios tienden a alcanzar su objetivo. Asimismo, las campañas más enriquecidas con información actualizada sobre sus avances y el uso de los fondos finalmente recaudados tienden a conseguir también su objetivo. Estos resultados se cumplen con independencia de la época del año en que se promuevan las campañas. 
Esta investigación revela un conjunto de implicaciones importantes para cualquier tipo de organización de economía social que intente financiar de forma colectiva causas sociales y establecer relaciones efectivas con nuevos donantes digitales, con el fin de lograr un crecimiento sostenible. Pero también implicaciones que pueden ayudar a empresas que promuevan CF solidario en el contexto de sus estrategias de responsabilidad social corporativa, con el fin de diseñar, gestionar y ejecutar eficazmente campañas para causas sociales. Implicaciones por ejemplo en el ámbito de la gestión y en relación con la programación de las campañas de CF solidario promovidas a través de plataformas digitales. También implicaciones relativas a la rendición de cuentas y la transparencia digital para generar y compartir contenidos que estimulen la creación de relaciones estables y de largo plazo con la comunidad de donantes, promover las donaciones, y contribuir a la financiación sostenible de la organización.

Reconocemos que el tamaño de la población analizada es la principal limitación de la investigación ( $\mathrm{N}=360)$. De manera similar, investigaciones futuras sobre $\mathrm{CF}$ solidario para causas sociales podrían recopilar datos adicionales e incluir un conjunto de variables de control independientes (i.e. número de promotores, objetivos, campañas previas exitosas, o grado de profesionalización) para ampliar aún más el alcance de los resultados de esta línea de investigación. También más investigación es necesaria para poder arrojar luz sobre la identificación de factores adicionales que expliquen el éxito de las campañas de CF solidario para causas sociales, evaluando por ejemplo el efecto de la divulgación de la campaña, las imágenes de la campaña y el diálogo en línea generado en torno a la campaña; o la capacidad explicativa de las características organizativas de las organizaciones promotoras, así como de su grado de alfabetización digital.

\section{Conclusiones prácticas y Valor original}

Podemos concluir que las campañas de recaudación de fondos promovidas por organizaciones de economía social para causas sociales se comportan de manera diferente fuera de línea y en línea, y por lo tanto las campañas de CF solidario a través de plataformas digitales cumplen con distintos criterios de éxito.

La principal contribución de la presenta investigación consiste en cubrir un vacío en la literatura emergente sobre la identificación de los factores determinantes del éxito de las campañas de CF solidario para causas sociales, revelando un conjunto de implicaciones que pueden ayudar a las organizaciones de economía social a establecer relaciones efectivas con un nuevo tipo de donante digital de cara a lograr un crecimiento sostenible.

PALABRAS CLAVE: Crowdfunding solidario; causas sociales; plataformas digitales; campañas de captación de fondos; organizaciones sostenibles de economía social. 


\section{Introduction}

Crowdfunding (CF) emerges in the new digital sphere as a tool for the online funding of resources, goods and services. Belleflamme et al. (2012) define CF as an open call via the Internet for the provision of financial resources to support the realization of initiatives for specific purposes. Despite being mostly related to monetary contributions, participation in CF is also possible by offering (in kind) products or services (De Buysere et al., 2012). The main CF models are based on equity, when funders receive compensation in the form of fundraiser's equity, revenue or profit-share arrangements, lending, when funders receive fixed periodic income and expect repayment of the original principal investment, reward, when funders' primary objective for funding is to gain a nonfinancial benefit or reward in return (token or first editions of products), and donation, when funders donate to causes just for the sake of supporting them, with no expected (material) compensation (Massolution, 2012). The focus of this research is precisely on this latter type of CF, and particularly on donation-based crowdfunding (DCF) through digital platforms (on-line portals to connect fundraisers and funders).

In the context of the ongoing digital revolution, DCF is growing rapidly among social economy organizations (SEO) striving for sustainable growth, including here not only social enterprises and other social-commercial hybrids, but also nonprofit organizations (NPOs) adopting commercial strategies for the public benefit (Rey-Garcia and Alvarez-Gonzalez, 2011). In a context of reduced access to traditional income sources and economic strains, this online tool complements, or even substitutes, the usage of both commercial strategies (sale of goods and services) and traditional, offline campaigns to raise donations for social causes (Rey-Garcia et al., 2013). The total funding volume reached worldwide by the CF donation model was estimated of \$2.85bn in 2015 (Massolution, 2015).

Funding social causes through the addition of charitable contributions coming from individuals is not a new practice by itself for these organizations; the real innovation lies in doing this through the Internet, given the wide ability of online contents in circulation to become viral (Gonzalo, 2011). Social media, for instance, allow interactive possibilities through text messaging services or social networking sites (SNS), particularly with individual and portable last generation devices such as smartphones, tablets or phablets. The use of these devices guarantees immediate and permanent access to a wide variety of opportunities for contribution and participation, unlimited by space and time. Thus, far from being once-only events, DCF campaigns become actual content within digital platforms. They guarantee the possibility of contributing in a vast simultaneous offer in which potential online donors will discriminate among social causes depending on their particular interests, neutralizing at the same time any possibility of campaign fatigue characteristic of offline contexts (van Leeuwen and Wiepking, 2013; Wiepking and van Leeuwen, 2013; Kinnick et al., 1996). 
However, and despite the increasing importance of DCF to promote prosocial values, successfully advance social programs, and become financially sustainable, little is the specific emerging literature. On the one hand, lending based campaigns have caught most of the attention within the broader CF literature. On the other hand, scarcely available studies on the particularities of DCF predominantly focus on the effects of this tool upon individual donors, rather than dealing with the effects of this manifestation of the digital revolution on promoters organizations. In particular, DCF literature pays attention to: (1) funding behaviors and the effects on reputation, (2) donors' satisfaction and self-esteem, (3) the role which giving has on improving the conditions of vulnerable people in developing countries, (4) the emerging trend for donors to use CF campaigns to articulate mass participation, and (5) the effect of tax incentives on giving (Gleasure and Feller, 2016).

In light of the above, this research ultimately aims at understanding the implications of DCF for the social economy and its organizations. In order to take advantage of the opportunities of the digital revolution, the promoters organizations need to identify what determines the success of their DCF campaigns for social causes. Do the rules of traditional, offline fundraising also apply in the new digital era? In this context, the main objective of this analysis is to explore the extent to which factors explaining the success of offline fundraising campaigns for social causes may also explain the success of DCF campaigns fostered through digital platforms.

In order to achieve this goal, we first characterize DCF campaigns and crowdfunding platforms (CFP). Based on a revision of the literature on the determinants of success of offline fundraising campaigns for social causes, we next propose a set of hypotheses linking those determinants to the outcomes of DCF campaigns through digital platforms. After explaining the methodology used, the explanatory capacity of the determinants will be put to test through an exploratory quantitative analysis based upon a database that stores 360 charitable campaigns fostered by small, medium and largesize NPOs via the DCF platform Microdonaciones, for the period between 2012 and 2017. Finally, we present the empirical results, main conclusions and implications.

\section{Literature review and hypothesis formulation}

\subsection{Donation-based crowdfunding campaigns promoted by SEO and crowdfund- ing platforms}

Crowdfunding (CF) campaigns consist of open calls by promoters or fundraisers to contribute to a wide variety of causes with different objectives (i.e. technological, scientific, creative, business, cultural, artistic or social objectives, among others). These can follow an all or nothing modality - the mon- 


\section{DETERMINANTS OF SUCCESS OF DONATION-BASED CROWDFUNDING THROUGH DIGITAL PLATFORMS: THE INFLUENCE OF OFFLINE FACTORS}

etary contributions are effective for contributors or funders (charged to bank accounts) and promoters (effective payment) only if the total amount requested is achieved by the deadline -, or a keep it all modality when monetary contributions are effective for contributors and promoters, regardless of the amount raised relative to the target.

As previously noted, CF campaigns specifically based on donation are a frequent model used by SEO for financing social causes, e.g. social care, education, research, culture, community development or environmental related. However, in addition to a funding channel, they also serve to increase their social support, disseminate charitable initiatives and social causes, create opportunities for civil engagement and generate the optimal conditions to create stable fundraising communities beyond the funding of occasional projects (Salvetti and Llombart, 2013).

Resulting from the development of Web 2.0-based technologies, CF campaigns are frequently channeled through new electronic spaces (e-marketplaces) via digital platforms. A digital platform is an online portal where users' authentication is required and commercial or noncommercial transactions between the parties involved are handled. It often provides other kind of services such as media hosting or social networking, increasing the online visibility of the operations and the variety of potential contacts between users and contributors (Danmayr, 2014). Crowdfunding platforms (CFP) can be own platforms - launched by the same promoters of the campaigns (i.e. individuals, entities or businesses) - or external - when third parties act as intermediaries between promoters and funders. The latter are especially recommended when promoters have no prior experience of launching and managing CF calls. Depending on the variety of campaign categories, CFP can be specialists when they host campaigns from the same category (i.e. charity), or general, when they host campaigns from a wide variety of categories (i.e. cultural, creative, social, technology). In terms of the geographical scope of the owner, CFP can be either national or franchises of global or international platforms. In the particular case of CFP for social causes under the donation model, there are a total of 103 currently active worldwide (CrowdsUnite, 2018). Specifically in Spain, $89 \%$ of charitable platforms are also based on the donation formula (Fondevila et al., 2015). Even so, the formulation of hybrid typologies (those mixing loan, investment, reward and donation operations) is a growing tendency for better alignment to the specific needs of campaigns and parties involved (Danmayr, 2014).

In the context of the scarce literature specific to DCF campaigns, we argue that it is reasonable to assume that some of the factors that influence the success of fundraising campaigns for social causes in the offline realm may also partly explain the outcomes of DCF campaigns. Therefore, instead of reviewing lending based CF research, we build our propositions regarding the donation model on the literature on traditional fundraising for charitable causes. In the following paragraphs, we review those factors in the literature on offline charitable campaigns and apply them to the digital sphere, in order to propose hypotheses about the determinants of success of DCF campaigns through digital platforms. 


\subsection{Determinants of success of offline fundraising campaigns in the context of donation-based crowdfunding for social causes}

Previous research has identified four sets of factors that determine the success of offline fundraising campaigns for social causes: 1) the geographic scope of the social cause - Where? - (Rey-Garcia et al., 2013; van Leeuwen and Wiepking, 2013; Wiepking and van Leeuwen, 2013; Bekkers and Wiepking, 2011); 2) the characteristics of target beneficiaries of the campaign - For Whom? - (Einolf et al., 2013; van Leeuwen and Wiepking, 2013); 3) the timing of the campaign - When? - (Einolf et al., 2013; van Leeuwen and Wiepking, 2013; Wiepking and van Leeuwen, 2013; Bekkers and Wiepking, 2011); and 4) the behavior of the promoter or fundraiser - How? - (Hou et al., 2017; Tremblay-Boire and Prakash, 2017; Beldad et al., 2015; van Leeuwen and Wiepking, 2013; Wiepking and van Leeuwen, 2013; Bekkers and Wiepking, 2011). We specifically draw on these determinants with the intention to build a set of hypotheses about their potential influence on the success of DCF campaigns promoted via digital platforms.

\section{Where: geographical scope of the social cause}

Geographical proximity between donors and beneficiaries has been demonstrated to positively affect the success of traditional offline fundraising campaigns (Wiepking and van Leeuwen, 2013). This indicator is mainly relative to physical proximity, but also involves social (or cultural) closeness between them, as donors living closer to beneficiaries will be more familiar with their respective cultures, giving "people a face" and increasing the empathy in situations of need.

Social causes can be domestic when they occur in the same geographical place where the potential donors belong, and, by extension, social/cultural similarities are potentially shared. On the contrary, causes abroad occur in distant geographical places where common social/cultural features among donors and victims are remote.

In general, people tend to give more to domestic causes than international ones (Bekkers and Wiepking, 2011). Nevertheless, empirical evidence suggests that the effects of proximity may vary across regions and countries. In the United States, donors tend to contribute to social causes occurring within their own country or in geographically close ones rather than those occurring in distant countries (for instance, funds raised for earthquakes victims abroad, were higher when affected countries were geographically closer). People also give more to populations with cultural and religious similarities or in historically associated countries. Along this line, an Australian study found that donors gave more to victims of earthquakes occurring in democratic countries (Einolf et al., 2013; van Leeuwen and Wiepking, 2013). By contrast, Dutch donors contribute more to international causes since the volume of campaigns promoted is higher in comparison to national ones (Wiepking and van Leeuwen, 2013). In Sweden, charity giving to domestic causes is socially perceived as a paternalistic measure when causes are within the scope of the welfare state. On the contrary, giving to underdeveloped countries is socially acceptable. Giving to international relief and natural disasters has actually been significantly 


\section{DETERMINANTS OF SUCCESS OF DONATION-BASED CROWDFUNDING THROUGH DIGITAL PLATFORMS: THE INFLUENCE OF OFFLINE FACTORS}

increasing in the country over the last decades, becoming more prevalent in number than campaigns for domestic causes (Vamstad and von Essen, 2013). Similarly, Spanish offline fundraising campaigns mostly have been focused on international humanitarian emergencies and natural catastrophes (ReyGarcia et al., 2013).

We argue that the effects of digital transformation may void the influence of geographical proximity in the case of DCF charitable campaigns via digital platforms. The Internet permanently amplifies the scope of the campaigns, beyond the limits of space and time characteristic of offline protocols, the only limit being the technical capacity and the ability to gain access. Digital coverage thus allows potential donors to "get a face" regardless of geographical distance, bringing social causes in close and permanent proximity to potential donors anywhere. Therefore, we expect a much more weakened, or even non-existent effect of domestic social causes on the success of DCF campaigns:

Hypothesis 1 (H1) Geographical proximity between donors and beneficiaries of social causes does not significantly affect the success of DCF campaigns through digital platforms

\section{For Whom: characteristics of target beneficiaries}

Previous evidence suggests that the number of potential victims assisted by an offline fundraising campaign affects their likelihood of succeeding, since it serves as an indicator of the scale of an emergency. Because of the feelings of empathy among potential donors, disasters with a large number of victims tend to raise more money. Along the same line, sudden and catastrophic disasters (i.e. tsunamis or earthquakes) tend to be more supported than slow-acting and gradual disasters such as famines and droughts (Einolf et al., 2013). Australian donors, for instance, gave 100 million Australian dollars in donations to the Asian tsunami victims in contrast to the 2 million raised for famine victims in the same year (van Leeuwen and Wiepking, 2013).

Since large-scale emergencies have a positive influence on the news value, large (and sudden) disasters gain more media attention and coverage, impacting the emergence of strong emotions of empathy among potential donors (Einolf et al., 2013). Previous studies of large scale natural disasters which occurred worldwide during the 1970s, '80s, and even the ' 90 s of the last century, support the explanatory capacity of the estimated volumes of victims on media attention (van Leeuwen and Wiepking, 2013). It is also true that, until not too long ago, it was virtually impossible to establish the final official numbers in the very short term once the disaster had happened, and gaps between the preliminary estimates of victims and the final number of casualties were frequent. On the one hand, online digital coverage significantly shortens these gaps: the use of personal, portable and increasingly technologically convergent devices, connected via the Internet, facilitates a more accurate and instantaneous update and dissemination of the final volume of real victims in need. On the other hand, coverage of disasters through online media feeds back contents to traditional media (e.g. through witness videos and testimonies), amplifying the perceived scale of the social cause in terms of number of people affected. 
In line with the aforementioned, we expect that the positive effect the volume of beneficiaries has on the success of offline fundraising campaigns will be further accentuated in the case of DCF campaigns:

Hypothesis 2 (H2) DCF campaigns through digital platforms focused on social causes involving larger volumes of potential beneficiaries are more likely to succeed than those involving smaller numbers.

\section{When: timing of the campaign}

The timing of a giving request affects the likelihood for an offline fundraising campaign to succeed, according to two different factors: 1) the stage of economic cycle in the country of potential donors; and 2) the time of the year: the specific time of the year when the campaign is held.

On the one hand, donating money entails monetary and psychological costs - the price of giving - yet on the other hand, giving can buy (fringe) material benefits for donors, for individuals known to them, or for a group of which the donor is a member (Bekkers and Wiepking, 2011). Some authors even equate philanthropic expenditures by wealthy individuals with consumption, as the donor would be ultimately acquiring material or psychological benefits such as status, reputation, or privileged access to institutions or networks for himself and his relatives (Reich, 2010). At a macro-economic level, one of the most prestigious sources of giving research in the world, Indiana University's Lilly Family School of Philanthropy, has proved a positive and significant influence of personal/household income and net worth on individual/household giving and nonprofit net worth on nonprofit giving (Lilly Family School of Philanthropy, 2018).

Thus, charitable giving seems to fluctuate along changes in the level of economic growth (Einolf et al., 2013). Offline fundraising campaigns held in periods of economic prosperity are more likely to succeed, simply because of the need for financial resources available to perform charitable donations. Individual perceptions of financial situations in the very short, medium and long term are also crucial determinants. While a secure economic situation will tend to influence a larger level and frequency of donations, a scenario of economic downturn will dissuade potential donors from contributing, and will encourage organizers of national campaigns (i.e. broadcasting companies, production companies, and charitable organizations) to invest less in large-scale national campaigns (Wiepking and van Leeuwen, 2013).

As regards the specific annual period, offline fundraising campaigns held around the end of the year are more likely to succeed. The volume of donations received during this period tends to increase because of more free time due to Christmas holidays, which increases the possibility of potential donors to be reached, as well as religious considerations, which may foster their need to enhance their moral reputation by making this period of the year into "a good time to give" (van Leeuwen and Wiepking, 2013). Furthermore, the end of the year is when individual donors tend to optimize their savings as taxpayers, thus reducing their cost of giving, since individual donations to SEO with a nonprofit status 
allow the possibility of tax savings, e. g. $75 \%$ from the first $€ 150$ donated and $30 \%$ from the following contributions in the case of Spain (AEF, 2015). As a consequence, we posit that

Hypothesis 3a (H3a) DCF campaigns for social causes through digital platforms run during economic rebound periods are more likely to succeed

and,

Hypothesis $3 b(\mathrm{H} 3 b)$ DCF campaigns for social causes through digital platforms run around the end of the year are more likely to succeed.

How: behavior of the promoting organization

Information asymmetry characterizes the relationship between donors and promoters organizations since the former are usually deprived of full (and updated) information on how their contributions are used (Beldad et al., 2015). The information provided and their effective and transparent behavior, is crucial to minimize the effects of toxic charity in the intention of giving, especially when charitable services are provided abroad (Hou et al., 2017; Tremblay-Boire and Prakash, 2017; van Leeuwen and Wiepking, 2013; Bekkers and Wiepking, 2011). In response to this information gap, potential donors may collect information on potential beneficiaries, as well as on the governance and previous performances of promoters, whether they intend to contribute offline or online. In this sense, quantity, quality and accessibility of information is crucial (Tremblay-Boire and Prakash, 2017).

Donors seem to contribute less when organizations are run inefficiently or the distribution of aid to victims is irresponsible and unfair, and consequently their contributions will not make a real big difference (Tremblay-Boire and Prakash, 2017; Einolf et al., 2013). SEO should therefore stimulate giving by behaving transparently and accountably since private donors look for guarantees that their contributions will reach the target beneficiaries as efficiently and effectively as possible (Wiepking and van Leeuwen, 2013). Provision of relevant information should not only be limited during the event, but also extend to the post-event stage, when donors will need to reassure their money has been spent effectively. In line with the aforementioned, we expect

Hypothesis $4 a(\mathrm{H} 4 \mathrm{a})$ DCF campaigns for social causes through digital platforms where the promoting organization provides information on the advances of the campaign are more likely to succeed

and,

Hypothesis $4 b(H 4 b)$ DCF campaigns for social causes through digital platforms where the promoting organization provides information on the funding uses are more likely to succeed. 
The conceptual model is depicted in Figure 1 as follows:

\section{Figure 1. Determinants of successful offline fundraising campaigns driving the success of DCF campaigns for social causes via digital platforms}

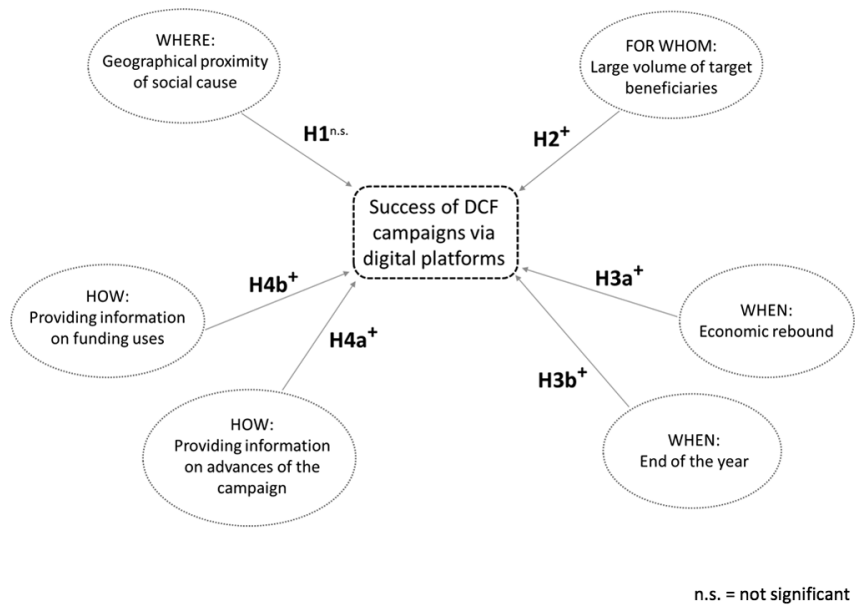

\section{Methodology}

\subsection{Selection of the donation-based crowdfunding platform for social causes}

The focus of this research is on an external, specialist, national and all-or-nothing DCF platform called Microdonaciones. Launched by Fundación Hazloposible in 2012, Microdonaciones was a digital platform aimed to promote giving of small amounts of money to charitable campaigns fostered by mostly Spanish NPOs, mainly foundations and associations. Donors could contribute either to a specific campaign, or via regular and monthly contributions to a portfolio of campaigns. There was neither a minimum nor a maximum amount for giving. Once the potential microdonor made the decision to start a donation process, he had to sign up as user in the platform, using an alias for the preservation of its identity if deemed appropriate. The campaigns hosted on the platform were distributed by categories according to their final purpose. For each campaign, online datasheets offered by default a set of details, including the title of the campaign, one related picture (at least), the name of the promoter, the requested 


\section{DETERMINANTS OF SUCCESS OF DONATION-BASED CROWDFUNDING THROUGH DIGITAL PLATFORMS: THE INFLUENCE OF OFFLINE FACTORS}

total budget and the total amount raised, the closing day of the campaign and the number of days left until the deadline, the volume of total target beneficiaries, and the volume of total donors heretofore as well as a brief narrative description on the aim of the campaign with related hyperlinks included. All the campaigns were active on the platform for a period of five weeks from their start-date, with a view to getting the monetary target requested.

The selection of Microdonaciones as donation-based CFP responded mainly to the following criteria. Firstly, the relevant intermediation and advising roles played by Microdonaciones with the promoting organizations, in addition to admittedly centralizing the resulting monetary transactions. Since charitable campaigns hosted in Microdonaciones were mainly promoted by small or medium sized organizations, their ICT skills could be minimal. In response to this limitation, Microdonaciones intermediated in the communication process between the promoters organizations and their potential donors' base, by creating and expanding their relationship through the exchange of contact data. Furthermore, Microdonaciones provided training and advice helping the development of ad-hoc effective communication actions focused on widely spreading their campaigns to reach as many people as possible. A second criterion was relative to the fact that the selection of the charitable campaigns to be finally hosted was standardized by the platform. This fact allowed us to limit the characteristic heterogeneity of the Spanish social economy sector (Alvarez-Gonzalez et al., 2017), favoring the estimation of the effect of the hypothesized factors on the success of the DCF campaigns via digital platforms. And finally, a third criterion had to do with the possibility of analyzing the effects of a donation-based CFP throughout its whole life cycle, since Microdonaciones completed its activity during the first quarter of 2017, five years exactly after its launching in the same stage of 2012.

\subsection{Data collection and population description}

In order to test our hypothesis, data on independent and dependent variables was gathered from Microdonaciones' official website. In particular, details of charitable campaigns were collected from the Microdonaciones' online datasheets.

A database was built from the information and data provided on the site, storing a total of 360 successful and unsuccessful campaigns fostered since March 19, 2012, when the first charitable campaign hosted started, until March 22, 2017, when the last campaign finished. Over this five-year time frame period, campaigns attracted over 9,300 online donations via the platform, resulting in 262 successful charitable campaigns, $73 \%$ of the total promoted (Table 1 ). 


\section{Table 1. Microdonaciones campaign effects in the period analyzed (2012-2017)}

\begin{tabular}{|ccccccc|}
\hline $\begin{array}{c}\text { Total } \\
\text { Campaigns }\end{array}$ & $\begin{array}{c}\text { Total } \\
\text { successful } \\
\text { campaigns }\end{array}$ & $\begin{array}{c}\text { Total } \\
\text { unsuccessful } \\
\text { campaigns }\end{array}$ & $\begin{array}{c}\text { Total } \\
\text { requested }(€)\end{array}$ & $\begin{array}{c}\text { Total } \\
\text { raised }(€)\end{array}$ & $\begin{array}{c}\text { Total } \\
\text { donors }\end{array}$ & $\begin{array}{c}\text { Total } \\
\text { beneficiaries }\end{array}$ \\
\hline 360 & 262 & 98 & 681,733 & 516,448 & 8,413 & 149,477 \\
\hline
\end{tabular}

SOURCE: Authors' own elaboration from Microdonaciones (Microdonaciones, 2017).

Regarding the characteristics of our population of 360 campaigns, and as described in table 2 , more than half responded to international causes (53\%) (i.e. those with targeted beneficiaries residing abroad), 44\% supported national causes (i.e. target beneficiaries residing in the country), and $3 \%$ focused on causes benefitting foreigners residing in the country (e.g. families/individuals temporarily residing in Spain such as war refugees, minors moved for medical treatments or surgeries, etc.).

The volume of potential beneficiaries was included in 272 campaigns (76\%) out of the total population of 360 , pointing towards a majority of micro campaigns. $59 \%$ of the campaigns targeted less than 100 potential beneficiaries, 14\% targeted between 101 and 1,000, 2\% targeted between 1001 and 10,000 , and the remaining $1 \%$ targeted over 10,000 potential beneficiaries.

Most charitable campaigns were run during the first and fourth trimesters of the year (from October to March, both months included), (59\%), followed by $26 \%$ of campaigns being run during the second trimester (April to June, inclusive) and 15\% during the third trimester (July to September, inclusive). $68 \%$ of the campaigns were held during a period of relative economic rebound (2014-2017). On the contrary, the remaining $32 \%$ were carried out within a context of economic crisis in the country (20122013).

As far as the additional information voluntarily provided by the promoters organizations within the campaign online datasheet is concerned, in $60 \%$ of the cases the promoting organizations updated information on the campaign advances. In $19 \%$ of campaigns, they provided details on the final funding uses raised during the campaign. 


\section{Table 2. Population description}

\begin{tabular}{|l|c|}
\hline Descriptors & $\begin{array}{c}\text { Volume of campaigns } \\
\text { in Microdonaciones } \\
\text { (N= 360) }\end{array}$ \\
\hline $\begin{array}{l}\text { The geographical scope of social cause } \\
\text { International }\end{array}$ & $53 \%$ \\
National & 44.2 \\
Foreigners in the country & 2.8 \\
\hline Volume of target beneficiaries ${ }^{\text {a }}$ & \\
From 1 to 100 & 58.6 \\
From 101 to 1,000 & 13.9 \\
From 1,001 to 10,000 & 1.7 \\
Over 10,000 & 1.4 \\
\hline Timing of campaign & 28.9 \\
1ts trimester of the year (Jan-Feb-Mar) & 26.3 \\
2nd trimester of the year (Apr-May-Jun) & 14.8 \\
3rd trimester of the year (Jul-Aug-Sept) & 30 \\
4th trimester of the year (Oct-Nov-Dec) & \\
Economic crisis (2012-2013) & 31.9 \\
Economic rebound (2014-2017) & 68.1 \\
\hline Information provided by the promoting organization & \\
Information on advances of the campaign & 59.7 \\
Information on funding uses & 18.9 \\
\hline
\end{tabular}

a) Applicable to $76 \%$ of the total campaigns.

SOURCE: Authors' own elaboration.

\subsection{Measuring the model variables}

Our dependent variable - the success of DCF campaigns - was operationalized as the attainment of the monetary goal requested in due time within the platform. As a dichotomous dependent variable, two possible values can be adopted: 1, when the monetary goal was achieved (successful campaign) and 0 in the contrary case, if funding raised did not suffice to reach the target goal (unsuccessful campaign). 
For each of the 360 charitable campaigns, we recorded data for a set of predictor variables. We used the geographical scope of the social causes to measure whether donations went to campaigns whose target beneficiaries were people who were not born (or resident) in Spain (international), people born or living in the country (national), or foreign beneficiaries residing temporarily in Spain (foreigners in the country). Data was obtained taking into account the imagery and narrative information included in the online datasheet of each campaign, where the specific origins of target beneficiaries were explicitly included.

We determined the volume of target beneficiaries based on the number of potential recipients in need specified per campaign on the Microdonaciones online datasheets. In the absence of an objective criteria used for quantifying potential beneficiaries in previous studies in this field, we set four intervals of target beneficiaries (Rey-Garcia and Alvarez-Gonzalez, 2011): From 1 to 100, From 101 to 1,000, From 1,001 to 10,000 and Over 10,000.

The moment of running the campaign was also relevant, given the concurrence of an economic crisis scenario during the period analyzed. In the particular case of Spain, early 2015 marked the turning point from which the upward trend of economic rebound in the country began to be perceived by Spanish households in terms of consumption (OCDE, 2017). The country's annual GDP rate was actually already showing positive signs of recovery in 2014 (INE, 2018), after passing through negative indicators during part of the economic crisis (i.e. 2008 - 4th quarter -, 2009, 2010 - 1st quarter -, 2011, $2012,2013)$. With this in mind, the start dates of the campaigns were calculated from closing dates, taking as reference the active period of five weeks for each campaign in the platform. According to the start dates, campaigns were allocated a GDP rate (positive or negative) depending on the quarter and the year they were undertaken. Thus, we categorized the campaigns held in 2012 and 2013 under the economic crisis period, and those undertaken from 2014 (inclusive) onwards as economy rebound period campaigns.

In order to test the explanatory capacity of the end of the year period as a determinant of success, campaigns were categorized based on their starting dates in Trimester 1 (January, February and March), Trimester 2 (April, March and June), Trimester 3 (July, August and September) and Trimester 4 (October, November and December) of each year between 2012 and 2017. Attending to the specific literature reviewed, we assumed that those campaigns initiated from October onwards and ready to catch the donors' online attention for the successive five weeks, would be undertaken within a period of growing pre-Christmas spirit that would predispose them to a greater success, in addition to the opportunity individual donors have to take advantage on the possibility of tax saving in this period. Taking into account the coexistence of different Christmas holidays calendars, and the application of tax savings formulas in different countries, and given that the volume of charitable campaigns promoted during the New Year period is still remarkable, we decided to also include those campaigns run during Trimester 1 of each year within the around of the end of the year period. 
Finally, we also considered the additional information voluntarily provided in each respective datasheet, in order to analyze the extent to which it explains the success of the online campaigns. Data was obtained paying attention to additional disclosures on the advances for each campaign in order to encourage the potential donors' commitment (i.e. ongoing thank you messages, motivational messages encouraging people to keep giving, etc.). In the case of additional information updated on the uses of funding finally raised, data was gathered paying attention to the narrative and campaign imagery added once the campaigns were over (e.g. listing of initial purchases vs. final purchases, audiovisual reports on preparations and/or results of activities scheduled, audiovisual reports on symbolic laying of "first stones" or final look of infrastructures, buildings or technologies, imagery from actual beneficiaries thanking/receiving/celebrating the target reached, etc.).

\section{Results}

As regards the potential influence that determinants of offline campaign success could have on the probability of achieving the monetary target requested in DCF campaigns, results of a logit model using STATA 13.0 MP for Windows are detailed in Table 3.

\section{Table 3. Effect of determinants of success of offline fundraising campaigns on success of DCF campaigns via digital platforms}

\begin{tabular}{|c|c|c|c|}
\hline Variables & Coef. & Std. Err. & $P>|z|$ \\
\hline \multicolumn{4}{|l|}{ Where: The geographical scope of social cause } \\
\hline National & -1.988 & 0.41 & 0.000 \\
\hline \multicolumn{4}{|l|}{ For Whom: Volume of target beneficiaries } \\
\hline From 1 to 100 & 4.015 & 0.48 & 0.000 \\
\hline \multicolumn{4}{|l|}{ When: Timing of campaign } \\
\hline Economy rebound (2014-2017) & 0.244 & 0.44 & 0.581 \\
\hline End of the year & -0.545 & 0.38 & 0.153 \\
\hline \multicolumn{4}{|l|}{ How: Information provided by the promoting organization } \\
\hline Information on advances of the campaign & 1.588 & 0.38 & 0.000 \\
\hline Information on funding uses raised during the campaign & 3.218 & 1.14 & 0.005 \\
\hline Constant & -0.434 & 0.54 & 0.423 \\
\hline Log likelihood & -94.558751 & & \\
\hline $\mathrm{N}$ & 360 & & \\
\hline LR chi2 & 233.72 & & \\
\hline Prob $>$ chi2 & 0.0000 & & \\
\hline Pseudo R2 & 0.5527 & & \\
\hline
\end{tabular}

SOURCE: Authors' own elaboration. 
Results show that the existence of geographical proximity among potential donors and beneficiaries of social causes negatively affects the success of DCF campaigns through digital platforms $(\mathrm{p}=0.000)$. Consequently, and contrary to both literature on traditional, offline campaigns and to our expectations, $\mathrm{H} 1$ is not supported.

Also contrary to expectations, a limited volume of potential beneficiaries of the DCF campaign has a positive effect on the success of the campaigns. Results reveal that the existence of less than 100 potential beneficiaries explains $(\mathrm{p}=0.000)$ the success of DCF campaigns performed to assist them. However, it should be borne in mind that the representativeness of the categories here analyzed is deeply uneven - i.e. from 1,001 to 10,000 and over 10,000 have 6 and 5 observations respectively -, whereas the category from 1 to 100 represents $59 \%$ of the total campaigns, $77.6 \%$ of the $272 \mathrm{cam}$ paigns including this data. Considering this mismatch, the latter happens to be the only truly substantial category. This having been said, and contrary to our expectations, $\mathrm{H} 2$ is not supported.

As far as factors underlying timing of the campaigns are concerned, neither have significant effects and hence do not explain the success of online campaigns. Neither was run in a period of economic rebound ( $p=0.581)$, nor around the end of the year $(p=0.153)$, determine the attainment of the monetary target requested by the deadline. Consequently, and contrary to expectations, the results do not support $\mathrm{H} 3 \mathrm{a}$ and $\mathrm{H} 3 \mathrm{~b}$.

Finally, the strong link between the inclusion of additional information voluntarily provided by the promoter organization and the success of DCF campaigns is seen. The voluntary inclusion of additional and updated information on the advances $(p=0.000)$ and the end-uses of funds raised $(p=0.005)$ in the context of the DCF campaigns, determines their success. Therefore, $\mathrm{H} 4 \mathrm{a}$ and $\mathrm{H} 4 \mathrm{~b}$ are supported.

\section{Discussion, Implications and Further Research}

The present study aims to contribute to the existing literature by analyzing the extent to which factors explaining the success of offline fundraising campaigns for social causes may also explain the success of DCF campaigns fostered by SEO via digital platforms. The major contribution consists thus of filling a gap within the emerging literature on the identification of determinants of the success of DCF campaigns for social causes. Employing the campaign as the unit of analysis, we focused on those determinants previously identified by the literature on the success of offline fundraising campaigns, specifically in relation to the geographical scope of the causes (Where), the volume of potential beneficiaries expected to be assisted (For Whom), the moment when campaigns are performed (When) and the behavior of the promoting organizations (How). 


\section{DETERMINANTS OF SUCCESS OF DONATION-BASED CROWDFUNDING THROUGH DIGITAL PLATFORMS: THE INFLUENCE OF OFFLINE FACTORS}

Firstly, results show the prevalence among successful DCF campaigns of those supporting causes not specifically domestic, but rather of those fostering causes aiming to assist geographically distant potential beneficiaries with whom it is relatively easy to empathize thanks to the digital coverage and the use of technological devices. This insight contradicts most of the literature reviewed about offline campaigns, but is consistent with evidence found in some countries such as Spain where campaigns for international humanitarian causes have been traditionally more successful than those for domestic causes (Rey-Garcia et al., 2013). Digital transformation seems to have brought international causes to very close proximity to potential donors thanks to the penetration of the Internet in the day-to-day realm and to the fact we can permanently access mobile devices.

Secondly, results show that successful DCF campaigns tend to mainly focus on social causes that involve a very limited volume of potential beneficiaries in need. Insights at this point are also in contradiction with literature on the success of offline fundraising campaigns, perceived as great events with a high impact related to the large number of resulting recipients (van Leeuwen and Wiepking, 2013). Under the digital paradigm, "small is beautiful", and donors seem to pay more credibility to micro projects, i.e. those targeting a small group of beneficiaries to whom they can put a face and help realistically. This is consistent with studies which claim that DCF donors tend to often contribute small amounts, preferring smaller goals campaigns and prefer to keep contributing when a goal is nearly met (Cockrell et al., 2016).

Thirdly, evidence shows that charitable giving via digital platforms is neither adjusted to economic fluctuations, nor connected to specific periods of the year, as opposed to offline fundraising campaigns. The insights derived here raise major managerial implications for the promoters organizations, basically in relation to the scheduling of DCF campaigns fostered via digital platforms. In a digitally dense world, every moment seems to be "a good time to give".

Fourthly, and finally, results show that successful DCF campaigns include details and information on the advances and the end-uses of the volume of contributions eventually raised. In this regard, relevant implications emerge again from a managerial perspective. Digital accountability and transparency seem key not only in order to minimize the characteristic information asymmetry in the relationship between the promoters organizations and their donor communities, but also for providing and sharing contents that stimulate the creation of stable, long-term relations, give donations and contribute to sustainable funding for the organization. This finding is consistent with research stating that the implementation of "share functions", favoring the spreading of campaign dialogue, may become equally crucial to finally gain potential donors' support and ensuring the campaign success (Aprilia and Wibowo, 2017; Gleasure and Feller, 2016; Byrnes et al., 2014).

Thus, in the realm of DCF campaigns through digital platforms, domestic causes tend to be less successful, while those with a limited number of target beneficiaries tend to reach their goal. Also, campaigns richer in updated information on their advances and the end-uses of funds raised tend to be more successful. These results hold regardless of the time of the year. In view of the results, we can 
conclude that fundraising campaigns fostered by SEO for social causes behave differently offline and online, and consequently DCF campaigns through digital platforms meet distinct criteria for success.

This research reveals a set of major implications not only for any type of SEO trying to crowdfund for social causes, but also for businesses involved in DCF in the context of their corporate social responsibility strategies, in order to effectively design, manage and run DCF campaigns for social causes. Digital transformation seems to have affected not only fundraising channels and tools, but also the nature of the fundraising campaign itself. Far from being once-only events (as traditional offline fundraising campaigns are), DCF campaigns via digital platforms constitute permanent content to be accessed, shared and commented through social networking sites (SNS) and beyond the media coverage effects on the social causes involved. Therefore, the DCF campaign is constantly evolving over time. The aim of a DCF campaign will thus go beyond the attainment of the monetary target requested and become essential for building an actively engaged audience around the cause, diffusing it among the network of contacts of potential donors, who in its turn will spread it once more, increasing the levels of funding and participation and guaranteeing the sustainability of the campaign (Byrnes et al., 2014; Outlaw, 2013). In particular, the information that is voluntarily disclosed in the campaign (e.g. narrative claims, description and picture/video imagery) may be useful to effectively impact potential donors and help them empathize with the social cause and its beneficiaries (Gleasure and Feller, 2016).

However, not only the nature of campaigns and the tools to develop them seem to have been digitally transformed. DCF in particular provides digital donors with the opportunity to join, and being part, of like-minded people online communities whereby showing social engagement, chance not encouraged so far by traditional charity formulas (Choy and Schlagwein, 2015). While warm glow and pure altruism may still play important roles, the donations of other peers feeding greatly the formation of expectations, since digital donors tend to give what they think they are expected to give (Gleasure and Feller, 2016; Smith et al., 2015). Implications of this research consequently may equally assist SEO in establishing effective relationships with new digital donors in order to achieve sustainable growth.

We acknowledge the limited size of the population analyzed as the main limitation of the research $(\mathrm{N}=360)$. Similarly, future research on DCF for social causes could serve to collect additional data and include a set of independent control variables (e.g. number of organizers, aims, prior successful campaigns, or the degree of professionalization) to further amplify the scope of the results of this line of research. Further research is also needed to shed light on the identification of additional factors explaining the success of DCF campaigns fostered by SEO for social causes, evaluating (1) the effect of the campaign design mix, based on the campaign disclosure, the campaign imagery and the campaign online dialogue; (2) the explanatory capacity of the organizational traits of the promoters organizations, and (3) the influence of their social media literacy and Web capacity. 


\section{References}

ÁLVAREZ-GONZÁLEZ, L.I., GARCÍA RODRÍGUEZ, N., REY-GARCÍA, M. \& SANZO PÉREZ, M.J. (2017): "Business-nonprofit partnerships as a driver of internal marketing in nonprofit organizations. Consequences for nonprofit performance and moderators", BRQ Business Research Quarterly, 20, 112-123.

APRILIA, L. \& WIBOWO, S.S. (2017): "The impact of Social Capital on Crowdfunding Performance", South East Asian Journal of Management, 11(1), 44-57.

ASOCIACIÓN ESPAÑOLA DE FUNDACIONES - AEF (2015): Régimen fiscal de los donativos, donaciones y aportaciones realizados a favor de las fundaciones acogidas a la Ley 49/2002, $<$ <ttp://www.fundaciones.org/EPORTAL_DOCS/GENERALAEEF/DOCcw5565970265664/InformaciOnfis calparadonantesdeduccionesnuevas.pdf>, last access August 24, 2018.

BEKKERS, R. \& WIEPKING, P.A. (2011): "Literature Review of Empirical Studies of Philanthropy: Eight Mechanisms That Drive Charitable Giving", Nonprofit and Voluntary Sector Quarterly, 40(5), 924973.

BELDAD, A., GOSSELT, J., HEGNER, S. \& LEUSHUIS, R. (2015): "Generous but not morally obliged? Determinants of Dutch and American Donors' Repeat Donation Intention (REPDON)", Voluntas, 26, $442-465$.

BELLEFLAMME, P., LAMBERT, T. \& SCHWIENBACHER, A. (2012): Crowdfunding. Tapping the wright crowd, <http://ssrn.com/abstract=1578175> last access October 11, 2017.

BYRNES, J.E.K., RANGANATHAN, J., WALKER, B.L.E. \& FAULKES, Z. (2014): "To Crowdfund Research, Scientists Must Build an Audience for Their Work”, PLOS ONE, 9(12).

CHOY, K. \& SCHLAGWEIN, D. (2015): "It affordances and donor motivations in charitable crowdfunding: The 'earthship kapita' case". In: 23rd European Conference on Information Systems, ECIS, Association for Information Systems.

COCKRELL, S.R., MEYER, D.W. \& SMITH, A.D. (2016): "Electronic intervention and platforms and their impacts on crowdfunding behavior", International Journal of Business Information Systems, 23(3), 263-286.

CROWDSUNITE website (2018): <http://crowdsunite.com/> last access January 28, 2018.

DANMAYR, F. (2014): Archetypes of Crowdfunding Platforms: A multidimensional comparison, Springer Fachmedien Wiesbaden, DOI: 10.1007/978-3-658-04559-3. 
DE BUYSERE, K., GAJDA, O., KLEVERLAAN, R. \& MAROM, D.A. (2012): Framework for European Crowdfunding, <http://www.crowdfundingframework.eu> last access May 12, 2017.

EINOLF, C., PHILBRICK, D. \& SLAY, K. (2013): "National giving campaigns in the United States: Entertainment, empathy, and the national peer group", Nonprofit and Voluntary Sector Quarterly, 42, 241-261.

FONDEVILA GASCON, J.F., RODRIGUEZ, J.R., MONFORTE, J.M., LOPEZ, E.S. \& MASIP, P.M. (2015): "Crowdfunding as a formula for the financing of projects: An empirical analysis", Revista cientifica Hermes, 14, 24-47.

GLEASURE, R. \& FELLER, J. (2016): "Emerging technologies and the democratization of financial services: A metatriangulation of crowdfunding research", Information and Organization, 26, 101-115.

GONZALO, P. (2011): "Dinero sin ánimo de lucro. Crowdfunding para monetizar el poder social", Compromiso Empresarial, $<$ https://www.compromisoempresarial.com/tercersector/ong/2011/08/dinero-sin-animo-de-lucrocrowdfunding-para-monetizar-el-poder-social> last access October 12, 2017.

HOU, J., ZHANG, C. \& ALLEN, R. (2017): "Understanding the Dynamics of the Individual Donor's Trust Damage in the Philanthropic Sector", Voluntas, 28, 648-671.

KINNICK, K.N., KRUGMAN, D.M. \& CAMERON, G.T. (1996): "Compassion fatigue: Communication and burnout toward social problems", Journalism and Mass Communication Quarterly, 73(3), 687707.

LILLY FAMILY SCHOOL OF PHILANTHROPY (2018): The Philanthropy Outlook 2017 \& 2018, <http://philanthropyoutlook.com/wpcontent/uploads/2017/01/Philanthropy_Outlook_2017_2018.pdf> last access January 15, 2018.

MASSOLUTION. THE CROWDFUNDING INDUSTRY REPORT (advanced version) (2015): $<$ http://www.crowdsourcing.org/editorial/global-crowdfunding-market-to-reach-344b-in-2015-predictsmassolutions-2015cf-industry-report/45376> last access November 15, 2017.

MASSOLUTION. THE CROWDFUNDING INDUSTRY REPORT (2012): <http://www.crowdsourcing.org/document/crowdfunding-industry-report-market-trends-composition-and-crowdfundingplatforms/14277> last access November 15, 2017.

MICRODONACIONES website (2017): <http://microdonaciones.hazloposible.org/> last access November 8, 2017.

NATIONAL STATISTICS INSTITUTE - INE (2018): <http://www.ine.es/prensa/pib_tabla_cntr.htm> last access January 13, 2018.

OCDE (2017): Estudios Económicos de la OCDE: España, <https://www.oecd.org/eco/surveys/Spain2017-OECD-economic-survey-overview-spanish.pdf>, last access October 21, 2017. 
OUTLAW, S. (2013): "Cash from the Crowd: How to crowdfund your ideas and gain fans for your success", Entrepreneur Press, 279.

REICH, R. (2010): "Toward a Political Theory of Philanthropy". In: Giving Well: The Ethics of Philanthropy, Illingworth, P., Pogge, T. \& Wenar, L. (Eds.), Oxford: Oxford University, UK.

REY-GARCÍA, M. \& ÁLVAREZ-GONZÁLEZ, L.I. (2011): "Foundations and social economy: conceptual approaches and socio-economic relevance", CIRIEC-España, Revista de Economía Pública, Social y Cooperativa, 73, Special Issue, 61-80.

REY-GARCÍA, M., ÁLVAREZ, L.I. \& VALLS, R. (2013): "The Evolution of National Fundraising Campaigns in Spain: Nonprofit Organizations between the State and Emerging Civil Society", Nonprofit and Voluntary Sector Quarterly, 42, 300-321.

SALVETTI \& LLOMBART (2013): El perfil del donante en España, $<$ https://www.afundacion.org/docs/socialia/informe_perfil_donante_espa\%c3\%b1a.pdf>, last access January 12, 2018.

SMITH, S., WINDMEIJER, F. \& WRIGHT, E. (2015): "Peer effects in charitable giving: Evidence from the (Running) field", Economic Journal, 125(585), 1053-1071.

TREMBLAY-BOIRE, J. \& PRAKASH, A. (2017): "Will You Trust Me?: How Individual American Donors Respond to Informational Signals Regarding Local and Global Humanitarian Charities", Voluntas, 28, 621-647.

VAMSTAD, J. \& VON ESSEN, J. (2013): "Charitable giving in a universal welfare state: Charity and social rights in Sweden", Nonprofit and Voluntary Sector Quarterly, 42, 285-301.

VAN LEEUWEN, M.H.D. \& WIEPKING, P. (2013): "National Campaigns for Charitable Causes: A Literature Review", Nonprofit and Voluntary Sector Quarterly, 42(2), 219-240.

WIEPKING, P. \& VAN LEEUWEN, M.H.D. (2013): "Picturing Generosity: Explaining the Success of National Campaigns in the Netherlands", Nonprofit and Voluntary Sector Quarterly, 42(2), 262-284. 
